University for Business and Technology in Kosovo

UBT Knowledge Center

Oct 27th, 1:00 PM - 2:30 PM

\title{
Characteristics of urban/architectural developments in Tirana and Prishtina, during the last decade
}

\author{
Binak Beqaj \\ University for Business and Technology, bbeqaj@ubt-uni.net \\ Armand Vokshi \\ University for Business and Technology
}

Follow this and additional works at: https://knowledgecenter.ubt-uni.net/conference

Part of the Architecture Commons

\section{Recommended Citation}

Beqaj, Binak and Vokshi, Armand, "Characteristics of urban/architectural developments in Tirana and Prishtina, during the last decade" (2017). UBT International Conference. 11.

https://knowledgecenter.ubt-uni.net/conference/2017/all-events/11

This Event is brought to you for free and open access by the Publication and Journals at UBT Knowledge Center. It has been accepted for inclusion in UBT International Conference by an authorized administrator of UBT Knowledge Center. For more information, please contact knowledge.center@ubt-uni.net. 


\title{
Characteristics of urban/ architectural developments in Tirana and Prishtina, during the last decade
}

\author{
Binak Beqaj, Armand Vokshi \\ UBT - Higher Education Institution, Prishtinë, Kosovë, \\ bbeqaj@ubt-uni.net
}

\begin{abstract}
Rapid urbanization as a process of societal transformation and intensive architectural developments in urban areas in Tirana and Prishtina, as capital cities of Countries in transition in sense of achievements for community living there and their urban qualitative life. Considering the planning process and role of different partners towards urban prosperity, the urban developments during the last ten years in both capital cities, based on research done and presented in this paper, using comparison methodology on some contextual bases:

- Policy context

- Physical spatial context

- Site landscape context

With analyses aiming to explain which are effects of three-dimensional mentioned above "contexts" related with: urban space and its integration within public realm (open space, streets, urban greenery, social features...) and architectural values related to sustainability, in line within general objective-urban community satisfaction!
\end{abstract}

Keywords: urbanization, architectural, community, process, urban, integration, sustainability.

\section{Introduction}

The thousand year's history of city development was related to relationships of the triangle: population-site- constructions. Most of the modern developments of the cities emerged 2000 years ago. By the IX-th Century in Europe, cities had extensively shaped: social, economic and politic life, from feudal towards industrial and post-industrial cities nowadays. This brought to urban rapid growth of the cities and its consequence's in relationships people-urban space! Most of the public spaces were overtaken by business and other activities, while: density, illegal constructions, informal settlements have been growing somewhere at the level of overloads and somewhere towards chaos! Those intensive urban developments (not) planned in a proper way, becomes as threats of social cohesion and spatial city composition on capitalist trends of modernity as well!

Urban planning as development power, has its rapid evolution too, starting from IX-th Century and on. First transforming medieval city and old quarters to new urban spaces centered to squares and boulevards, organizing city blocks as multifunctional areas followed by greenery and public spaces, all this in good relation with traffic flow and communication network too. 


\section{State of the art}

Prishtina, from period of the ottoman's empire and characteristically architecture from that period dominated by concepts of "Carshia" and "Mosque" as dominant urban referent spaces, was transformed to period of after second World-War (year 1945), as city of 20.000 inhabitants characterized from the dominant development of "Social housing", "Administrative, university and industrial center" too. Nowadays after the last liberation war (year 2000) Prishtina continued to become as biggest city of Kosova with 198.000 inhabitants with rapid development as result of population concentration, investments and opened development perspective, while Tirana before second World war with ottoman, Austro-Hungarian and Italian influence becomes biggest city of Albania and its capital city, but, after societal and political transformations (1990), becomes a city with over than 800.000 inhabitants, characterized with rapid development as result of population concentration, investments and opened multifunctional development perspective for its citizens.

As result of rapid urban development of both cities, inner city areas have been degraded (with over constructions and illegal constructions and reduction of greenery and public spaces too), while peripheral areas have been spatially degraded by informal settlements in most cases as lack of systemic and adequate urban planning and development.

\section{Research work, study cases}

It is well known that rapid urbanization is accompanied by high concentration levels and high density, massive constructions in inner city urban area, and urban sprawl towards periphery too. All this have impacts related to the feelings and behaviour of citizens in relation with urban life, so, it is significant answering the question:

$>$ At what level urban/ architectural transformations in the city, can create urban sense of community living there?

So far, the urban development practice of the cities in transition, was mainly concentrated in terms of: revitalizing and maintaining some of existing urban areas, developing some new urban areas, caring for commercial corridors; all this in context of planned or not planned/informal settlements, legal and illegal constructions, in most cases without systemic chronology of development! Therefore the question is:

$>$ What makes them "qualitative urban areas" and by which parameters can be determined and classifyed urban quality?

In order to answer raised questions, was used a research methodology called "Customer Preferences for the Product" which was applied as modified methodology like "Citizen Preferences for Urban/ Architectural Developments in the City" also known as "Utility Method". By using questionnaires for both case studies, this method shows citizens preferences on actual urban solutions and also their future preferences on the architectural modification on the urban area where do they belong. In addition the following indicators are used as valuators for citizen preferences of urban/ architectural form and structure:

- Presentation (materialization)

- Perception (perception and integration)

- Integration (shape, complexity, harmony)

- Socialization (showing reflection on behaviour)

- Aesthetics (colours, rhythm )

From both case studies, performed in Prishtina and Tirana, there is a confirmation that urban/ architectural improvements can be considered as indicators of success in changing the overall urban space, and also with influences in community behaviour in terms of how do they see them, how do they use them or re-use them in the context of their socio-economic dynamics. The 
research was done during June 2017 in both cities, measuring citizens opinion by interviews and surveys (220 citizens of different categories from each city), with main focus on key raised measurement factors, related to the development of urban space: multi-functionality, infrastructure, public space and public realm, social stability, public health, and urban governance. The figures shown as below, presents citizens opinion for urban architectural developments in Tirana and Prishtina, during last decade!

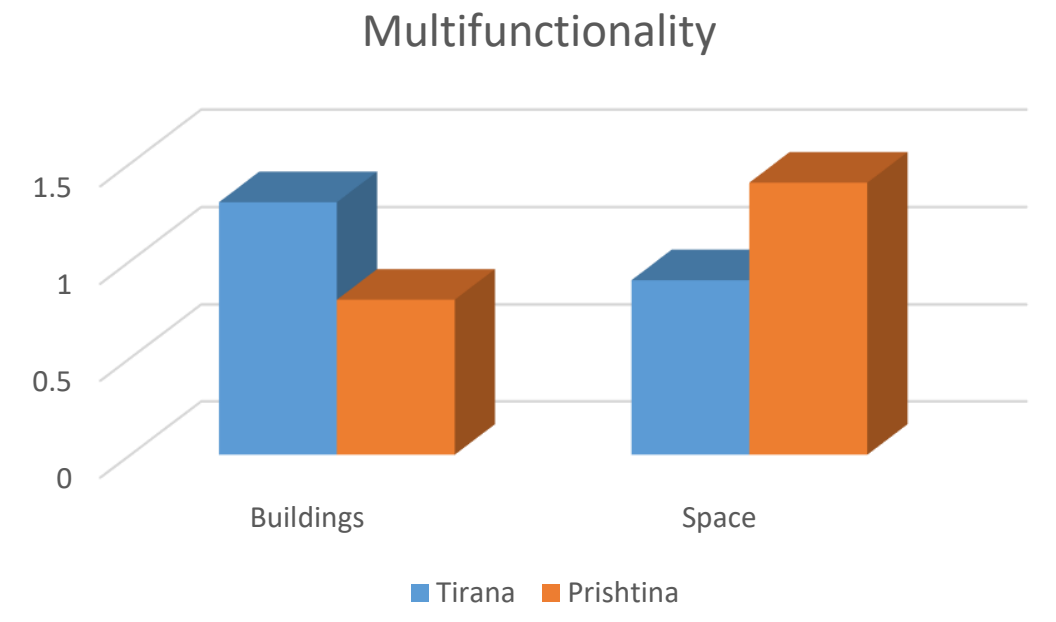

Fig.1. Citizens opinion about urban/ architectural multi-functionality, developed during last decade (source: research work, June 2017)

Multi-functionalty was evaluated as impact factor on quality of urban life for citizens, the system called "One Stop Shop". As it is shown in Fig.1, multi-functionality as phenomena, during last decade was more related to the buildings in Tirana, while in Prishtina was more related to the urban space. Considering in general, multi-functionality in both cities was related to the combination of architectural and spatial context. 


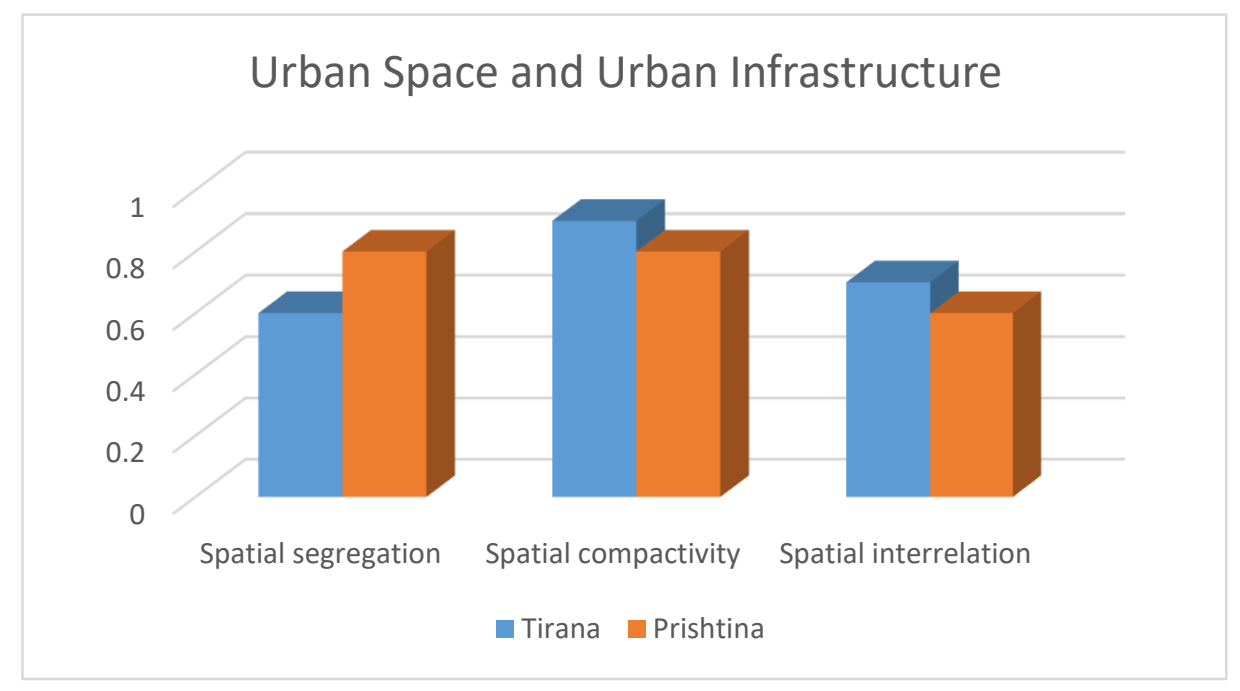

Fig.2. Citizens opinion about urban infrastructure, developed during last decade (source: research work, June 2017)

Urban Infrastructure was evaluated as impact factor on quality urban life of citizens too, the concepts based on "Equity on Movement Flow". As it is shown in Fig.2, urban infrastructure as network, developed during last decade was more related to the spatial compactivity and spatial segregations and less to the spatial interrelation in both study cases.

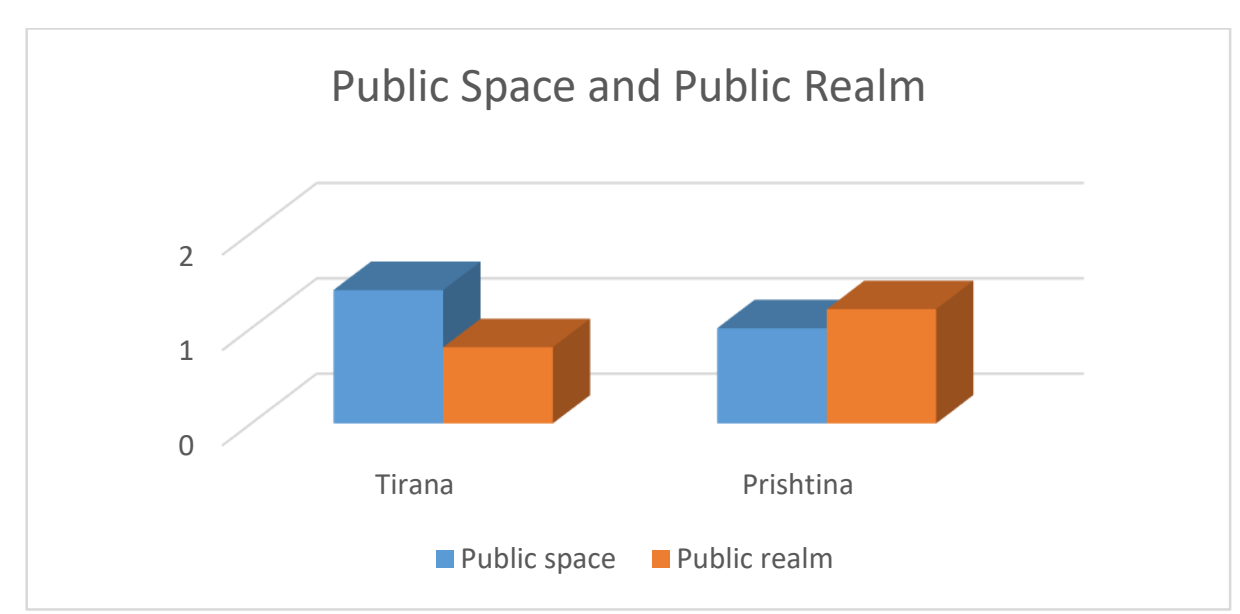

Fig.3. Citizens opinion about public space and public realm, developed during last decade (source: research work, June 2017)

Public space in relation with public realm, was another issue evaluated related with quality urban life for citizens, because both must complement each other, in order to fulfil citizen's needs and requests in compliance with their urban activities. That disproportion is more evident in Prishtina. 


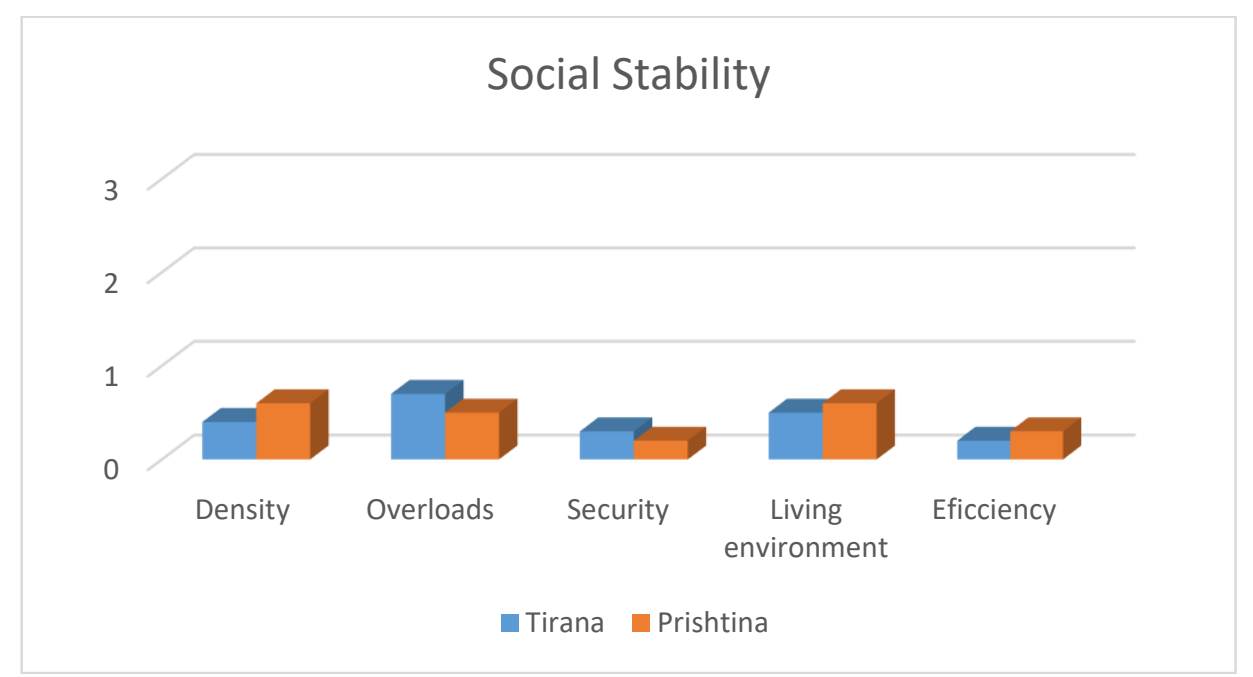

Fig.4. Citizens opinion about social stability, developed during last decade (source: research work, June 2017)

Social stability was evaluated too, as an impact factor on quality urban life with some of its components. Some of components are considered more dominant in Tirana (like overloads), while some of them are more dominant in Prishtina (like living environment). Presented parameters are general concern of urban/ architectural city developments with impact on social stability.

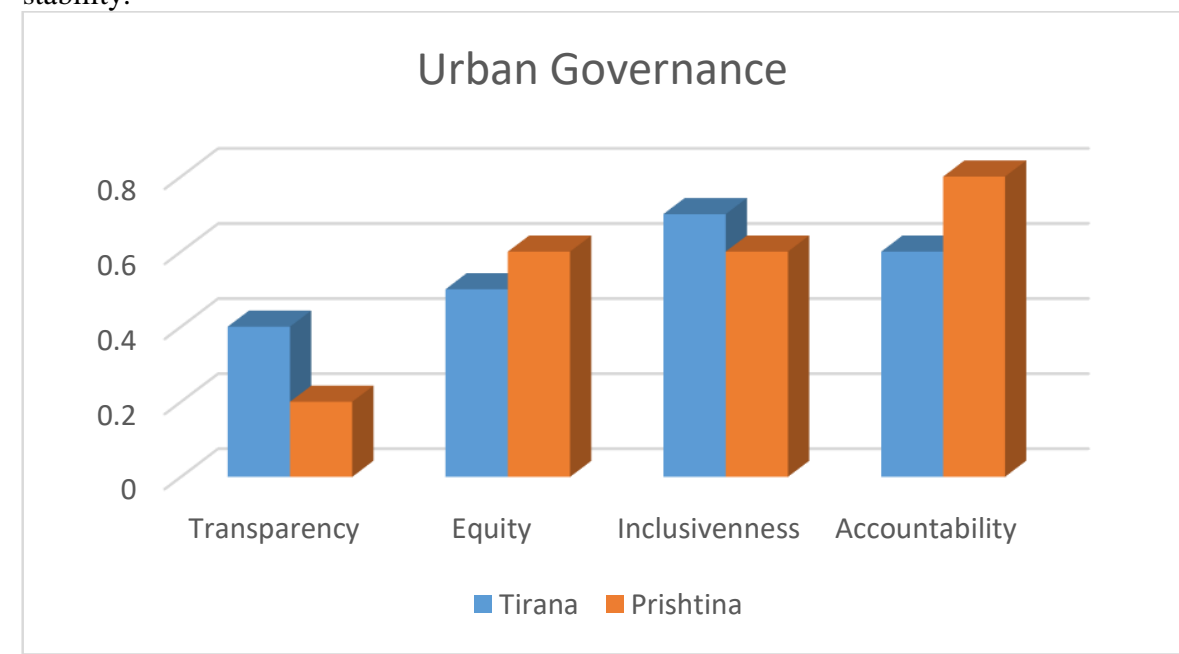

Fig.5. Citizens opinion about urban governance, developed during last decade (source: research work, June 2017)

Urban Governance, was evaluated as indirect impact factor on quality urban life for citizens and urban development in general. As it can be seen in Fig.5, more evident problem for Prishtina is considered transparency and inclusiveness, while equity and accountability are not in satisfactory level in Tirana! 


\section{Conclusion}

Considering that urban planning is designed as system dealing with urbanization towards qualitative urban life, using rationally all resources and potentials for public interest and considering peoples welfare there, it's understandable that people needs qualitative standards regarding shelter, work, transport, recreation, proactivity and participation in processes inside urban area, in the way that city should be:

- Livable City

- Attractive City

- $\quad$ Safe City

- Sustainable City

"City in Regional Context", "City as Destination", "City as Place", are some of the literature notions regarding urban development. To fulfill those above mentioned development concepts for the city, should be taken into a consideration, some of essential preconditions: professional human resources, case studies and good experiences, location and regulatory measures in correlation with economics, social and cultural development, environment protection and movement/communication too.

Finally, can be concluded that those developing issues, were followed by the reciprocal interrelation between natural, building and social factors:

- Urban policies, planning concepts

- Urban economy, development systems

- Urban sociology, tradition and behavior of citizens

- Urban geography, spatial extension of the cities

- Building style and technology

All this in relation of competiveness of the city in many aspects: social, functional, morphological, structural model and landscape.

\section{References}

1. Stephen Carr, (1993) "Public Space", Cambridge University Press

2. Setha M. Low, Neil Smith, (2006) "The Politics of Public Space”, Routledge

3. Peter John, (2012) “Analyzing Public Policy”, Routledge

4. Binak Beqaj, (2015) "Urban Development, Planning and Design”, UBT

5. Jan Gehl, (2011) "Life Between Buildings Using Public Space", Island Press

6. Jan Gehl, (2010) "Cities for People”, Island Press

7. Charles Montgomery, (2013) "Transforming Our Lives Through Urban Design", Dubleday Canada

8. Binak Beqaj, (2007), “Urban Management”, UBT

9. Frederick Steiner, Kent Butler (2006) „Planning and Urban Design Standards“, Willey Graphic Standards

10. Robert Cowan, (2005) ,"The Dictionary of Urbanism”, Streetwiae press

11. Kevin Lynch, (1960), "The Image of the City”, MIT Press

12. James A. LaGro, Jr. (2013), "Site Analysis: Informing Context-Sensitive and Sustainable Site Planning and Design", John Viley and sons INC 